D. B. Moore, Section Manager

Authorized Derivative Classifier

RECOVERY OF CONTAMINATED WETLAND SOILS AT SRS BY NATURAL RAINFALL: AN EXPERIMENTAL, TOXICOLOGICAL STUDY (U)

Craig Loehle

Approved by D Brocel

D. B. Moore, Section Manager

Environmental Sciences Section

Publication Date: August 1990

Westinghouse Savannah River Company Savannah River Site

Aiken, SC 29801 
WSRC-RD-90-14

\title{
RECOVERY OF CONTAMINATED WETLAND SOILS \\ AT THE SAVANNAH RIVER SITE BY NATURAL RAINFALL: AN EXPERIMENTAL, TOXICOLOGICAL STUDY (U)
}

\author{
by \\ Craig Loehle \\ Westinghouse Savannah River Company \\ Savannah River Site \\ Aiken, South Carolina 29808
}

\begin{abstract}
A laboratory study was conducted to evaluate the potential for natural remediation of contaminated wetland soils by rainfall. Contaminated soils were collected and leached repeatedly with rainwater. After 6 leachings the leachate was observed to be non-toxic to lettuce seedlings, whereas the initial leachate was very toxic. These results suggest that more detailed studies on leaching as a remediation technique could be beneficial.
\end{abstract}

\section{INTRODUCTION}

In support of remediation efforts for the Savannah River Site (SRS) wetlands, damaged by outcropping contaminated groundwater, this pilot study examined the efficacy of natural rainfall for removal of contaminants from SRS soils. Rainwater percolating through soils is capable of carrying away mobile ions such as soluble salts (USDA, 1954). If this natural process, perhaps enhanced with irrigation, is capable of removing a sufficient amount of the contaminating constituents, then this may be a potential remediation strategy. Irrigation is commonly used in agriculture to remove salt (USDA, 1954).

This study was conducted at the Department of Energy Savannah River Site in South Carolina. Seepage basins at the SRS F-Area received liquid effluent from the 1950s to 1988. This effluent was typically acidic, containing high amounts of total dissolved ions, low levels of tritium and other radioactive elements, and trace levels of various heavy metals (Killian et al., 1987). Sodium (from $\mathrm{NaOH}$ ), and aluminum [from soil matrix reduction due to acid leachate (Bertsch, 1989)] were at particularly high levels in the outcropping water and were the most likely causes of tree death (Loehle, 1990). The effluent gradually seeped down to the water table and subsequently outcropped along the edge of a forested wetland bordering Four Mile Creek. In areas where high concentrations of this contaminated water has outcropped in the wetlands, hardwood forest vegetation, mostly swamp tupelo (Nyssa sylvatica var. biflora), has been killed (pers. obs. and Mackey, 1988).

\section{DISCUSSION}

The ideal experimental technique would be to collect an intact soil core and slowly leach water through it. Unfortunately, the soils studied are wetland soils with a very loose structure that completely collapses when disturbed. This eliminates all free drainage and clogs any filters put at the bottom of a soil core tube. Therefore, it was necessary to design a study that would simulate the natural percolation of rainwater, to the maximum extent possible, within the constraints of this soil type. 
The basic technique designed for this study was to mix the soils and water by moderate shaking, equilibrate, remove the water, and repeat the process, collecting the leachate after each step. The water recovered at each step was then used to grow plant seeds in petri dishes.

\section{Method}

Saturated wetland soils were collected from three locations in the contaminated FArea site and a control site (Figure 1). Coring tubes were used to extract soil from the ground surface to a depth of 18", then the excess water was drained off. Soils were air dried and then analyzed for chemical constituents (Richardson et al., 1990).

Rainwater collected by SRS Health Protection was used for extractions. Extractions were performed using $100 \mathrm{~g}$ of the air dried soils placed in $250 \mathrm{ml}$ plastic bottles and wetted with $150 \mathrm{ml}$ of rainwater. One sample was used from the control site and three from the F-Area contaminated zone (three separate sample locations). Each bottle was shaken 5 times initiaily and allowed to equilibrate for four days to ensure rewetting. Shaking was very effective in mixing the soil and water to create a slurry. On each day of equilibration each bottle was shaken again. The samples were not continuously tumbled, as this would have fragmented the organic material and exposed additional exchange sites. After equilibration the soils were centrifuged to extract most of the water. The water extracted was filtered through 0.45 micron acid washed filters. Extracted water from the three contaminated site samples was combined. The extracted water samples were then stored (refrigerated at $4^{\circ} \mathrm{C}$ in the dark). The soils in each bottle of the contaminated samples were then wetted with an additional $100 \mathrm{ml}$ of rainwater, shaken, and allowed to equilibrate for two days to obtain the second leachate. This process was repeated until six leachate samples were obtained. The uncontaminated sample of soil was leached only once to simulate pore space water for undisturbed soil under saturated conditions. All leachates were then analyzed for $\mathrm{pH}$, conductivity, major anions, cations, and metals by personnel of the Analytical Development Section at Savannah River Laboratory.

Once all the extractions had been performed, toxicity tests were conducted using the standard method developed by Carlson, et al.(1989). For each leachate treatment, 8 petri dishes with 10 seedlings of commercial Bibb Butterhead lettuce in each were tested. Lettuce seedlings were chosen because they are fairly sensitive to toxic substances. The number of seeds germinating per dish was one test variable. The mean radicle length for all germinated seeds (combined over all dishes) was the other test variable. Seeds were placed on a Whatman \#5 filter wetted with $2 \mathrm{ml}$ of water and the dish sealed with parafilm. Measurements were made after 3 days of growth. The test treatments were plain rainwater (rain), uncontaminated soil leachate 1 (control), and contaminated F-Area soil leachates 1 and 6 (F1, F6). "Rain" and "Control" act as controls. The petri dishes were arranged on the counter in a random design at room temperature and given a regular period of 9 hours of light per day. 


\section{RESULTS}

Table 1 shows the effe $w$ of the leaching procedure on soil water chemistry. Leaching caused major reductions in ions. Water chemistry in F6 was very similar to the control soil for most major ions. The $\mathrm{pH}$ increased from 4.71 (in F1) to 5.11 (in F6) due to the higher $\mathrm{pH}(6.3)$ of the rainwater. The main suspected toxic constituents exhibited major declines:

$\begin{array}{lccc}\text { Nitrate } & 424 \mu \mathrm{g} / \mathrm{ml} & \text { to } & 55.3 \mu \mathrm{g} / \mathrm{ml} \\ \text { Cadmium } & 0.039 \mu \mathrm{g} / \mathrm{ml} & \text { to } & 0.007 \mu \mathrm{g} / \mathrm{ml} \\ \text { Manganese } & 6.32 \mu \mathrm{g} / \mathrm{ml} & \text { to } & 1.26 \mu \mathrm{g} / \mathrm{ml} \\ \text { Alurninum } & 7.09 \mu \mathrm{g} / \mathrm{ml} & \text { to } & 1.69 \mu \mathrm{g} / \mathrm{ml} \\ \text { Sodium } & 121.1 \mu \mathrm{g} / \mathrm{ml} & \text { to } & 15.3 \mu \mathrm{g} / \mathrm{ml}\end{array}$

Since only one water sample was analyzed for each treatment, no statistical analysis could be performed, but the reduction in ions was major and consistent across each of the suspect constituents.

Results showed that the first leachate from the contaminated soil (F1) was toxic to the lettuce seeds, both in terms of germination (Table 2) and in terms of root growth (Table 3). For statistical testing, the germination data were converted to percent and then an Arcsin [square root $(x)$ ] transformation applied. Duncans multiple range test was applied with $p=0.05$. Germination in F6 leachate did not statistically differ from the rain treatment ( $p \leq 0.05$ level). The control treatment differed slightly from the rain and F6 treatments. F1 was different from the others. These results (Figure 2) show rain, control and F6 to be largely equivalent and much better than $\mathrm{F} 1$ for seedling growth, indicating a beneficial effect of leaching on soil quality.

Results for root length are basically similar to those for toxicity (Figure 2, Table 3). A dish effect was investigated and found to be insignificant. Therefore, all seedlings within a treatment were pooled. Pairwise comparisons were made between treatments using a ttest. The nominal significance level of 0.05 was adjusted for multiple comparisons using the Bonferoni adjustment, giving 0.01 as the acceptance level for significant differences. Mean root lengths for rain, control, and F6 treatments were not different from each other. Rain and control differed from F1, but F6 and F1 differed only at ne 0.05 level. These results show that the levels of all soil water ions in Table 1 under F6 are below the toxic level, as indicated by the good root growth and germination results.

\section{CONCLUSIONS}

These results indicate that rainfall is capable of removing mobile ions from these soils. Additional detailed laboratory and field studies will be necessary to obtain more precise data. Points that require further analysis include:

1. What is the effect of more realistic, in sim conditions.

2. What constituents are released by leaching.

3. What is the condition of the residual soil after leaching for plant growth? 


\section{ACKNOWLEDGMENTS}

This work was performed under contract DE-AC09-89SR18035 with the U.S. Department of Energy, with whom the copyright remains. Thanks to Aubrey Carroll for laboratory assistance, to Paul Bertsch, Claire Carlson, and Curtis Richardson for experimental design advice, and to Paul Bertsch, Ken McLeod, Carl Strojan, and Tony Towns for field assistance.

\section{REFERENCES}

Bertsch, P.M., 1989, "Aluminum Speciation: Methodology and Applications, pp 63-105, D.C. Adriano and W. Salomons, Eds., Advances in Environmental Science. Acidic Precipitation, Vol. 4: Soils, Aquatic Processes, and Lake Acidification. Springer-Verlag, NY.

Carlson, C.L., Kaplan, D.I., and Adriano, D.C., 1989. Effects of Selenium on Germination and Radicle Elongation of Selected Agronomic Species.

Environmental and Experimental Botany 4: pp 493-498.

Killian, T.H., Colb, N.L., Corbo, P., and I.W. Marine, 1987. Environmental Information Document F-Area Seepage Basins. DPST-87-704, E.I. du Pont de Nemours and Co.,Inc., Savannah River Laboratory, Aiken SC 29808.

Loehle, C., 1990. Assessment of Tree Toxicity near the F- and H-Area Basins of the Savannah River Site. WSRC-TR-90-253, Westinghouse Savannah River Company, Savannah River Laboratory, Aiken, SC 29808.

Mackey, Jr., H.E., 1988. Initial Evaluation of Photographic Data of F- and H-Area Seepage Basin Outcrops. DPST-88-314, E.I. du Pont de Nemours and Co., Inc., Savannah River Laboratory, Aiken SC 29808.

USDA, 1954. Diagnosis and Improvement of Saline and Alkali Soils. USDA Handbook 60. 


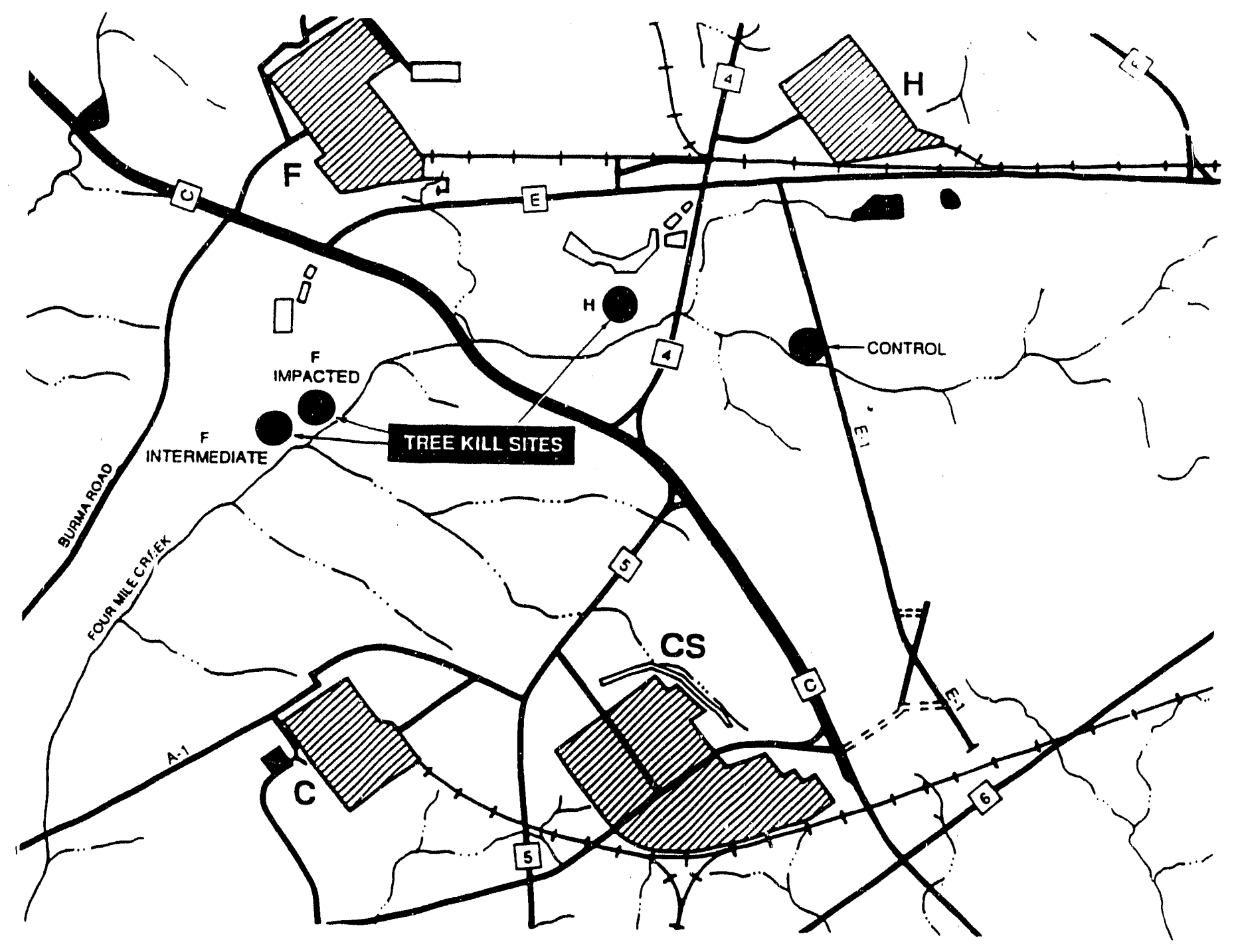

Figure 1. Map of Study Site Locations at SRS 

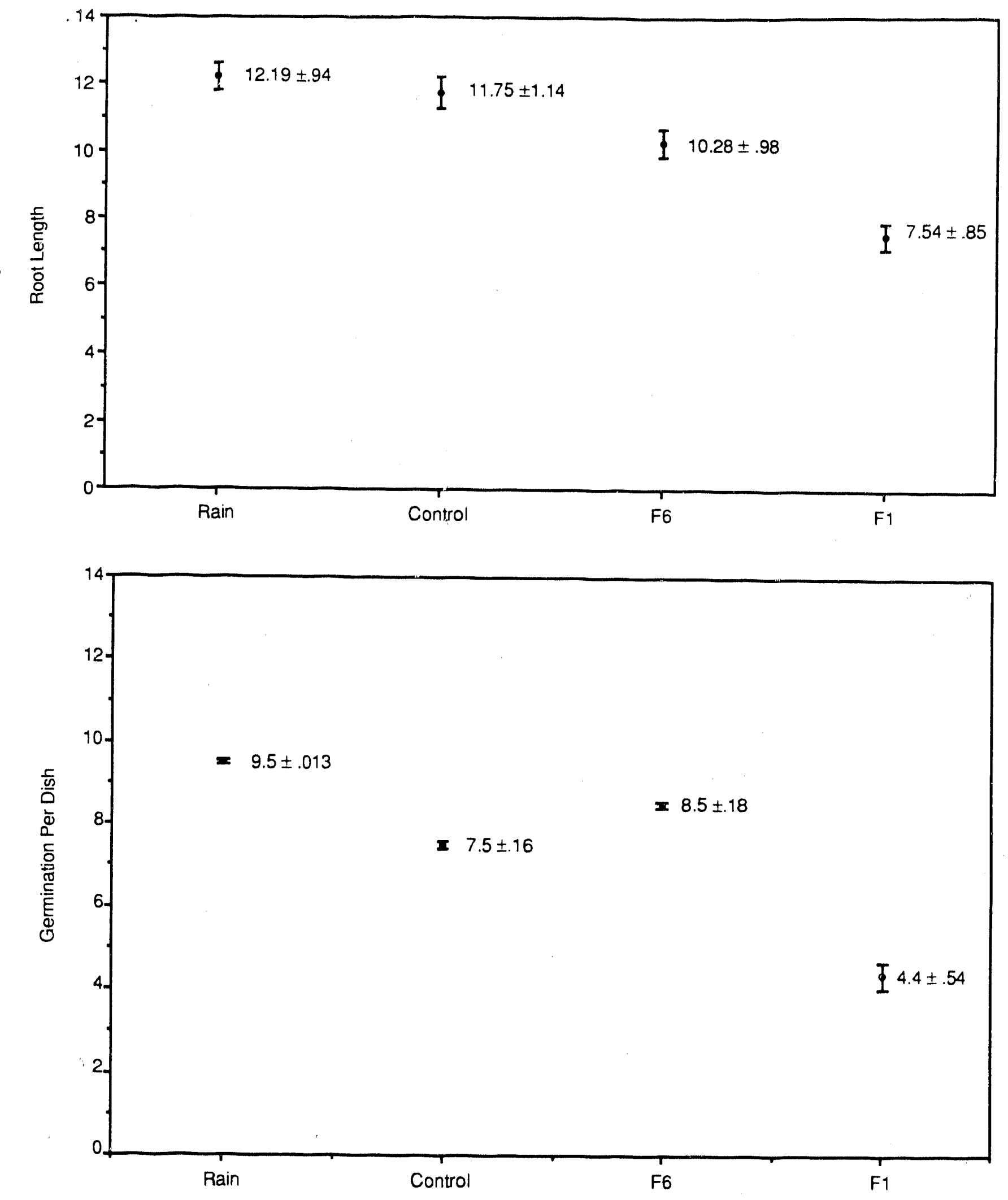

Figure 2. Results of Seedling Study.

F1 is the Initial Leachate from the Contaminated Soil Samples. F6 is the Sixth Leachate from the Contaminated Soil Samples. Germination per Dish is a Count, out of a possible 10. Root length is in $\mathrm{mm}$. 
Table 1. Water Chemistry Analyses for Seedling Experiment.

\begin{tabular}{|c|c|c|c|c|}
\hline & Rain & Control & F6 & $\mathrm{F} 1$ \\
\hline $\mathrm{pH}$ & 6.23 & 5.56 & 5.11 & 4.71 \\
\hline conductivity (mmhos) & 0.016 & 0.104 & 0.134 & 0.794 \\
\hline nitrate $(\mu \mathrm{g} / \mathrm{ml})$ & $<1.5$ & 3.71 & 55.3 & 424.0 \\
\hline nitrite $(\mu \mathrm{g} / \mathrm{ml})$ & $<1$ & $<5$ & $<5$ & $<5$ \\
\hline sulfate $(\mu \mathrm{g} / \mathrm{ml})$ & 1.29 & 15.4 & 2.25 & 25.0 \\
\hline $\mathrm{Ca}(\mu \mathrm{g} / \mathrm{ml})$ & 0.381 & 1.373 & 2.524 & $>13.509$ \\
\hline $\mathrm{Cd}(\mu \mathrm{g} / \mathrm{ml})$ & 0.001 & $<0.001$ & 0.007 & 0.039 \\
\hline Co $(\mu \mathrm{g} / \mathrm{ml})$ & 0.417 & $<0.004$ & 0.029 & 0.104 \\
\hline $\mathrm{Cu}(\mu \mathrm{g} / \mathrm{ml})$ & 0.002 & 0.060 & 0.011 & 0.099 \\
\hline $\mathrm{Mg}(\mu \mathrm{g} / \mathrm{ml})$ & 0.088 & 0.543 & 0.613 & 4.846 \\
\hline $\mathrm{Mn}(\mu \mathrm{g} / \mathrm{ml})$ & 0.011 & 0.045 & 1.259 & 6.316 \\
\hline $\mathrm{Pb}(\mu \mathrm{g} / \mathrm{ml})$ & $<0.020$ & $<0.020$ & $<0.020$ & $<0.020$ \\
\hline $\mathrm{Zn}(\mu \mathrm{g} / \mathrm{ml})$ & 0.053 & 0.031 & 0.077 & 0.133 \\
\hline $\mathrm{Zr}(\mu \mathrm{g} / \mathrm{ml})$ & $<0.002$ & $<0.002$ & $<0.002$ & 0.015 \\
\hline $\mathrm{Al}(\mu \mathrm{g} / \mathrm{ml})$ & $<0.010$ & 0.870 & 1.686 & 7.090 \\
\hline $\mathrm{Ba}(\mu \mathrm{g} / \mathrm{ml})$ & 0.005 & 0.015 & 0.155 & 0.660 \\
\hline $\mathrm{Fe}(\mu \mathrm{g} / \mathrm{ml})$ & $<0.002$ & 0.265 & 0.309 & 0.204 \\
\hline $\mathrm{La}(\mu \mathrm{g} / \mathrm{ml})$ & $<0.003$ & $<0.003$ & 0.004 & 0.057 \\
\hline $\mathrm{Li}(\mu \mathrm{g} / \mathrm{ml})$ & $<0.001$ & $<0.001$ & 0.001 & 0.001 \\
\hline Mo $(\mu \mathrm{g} / \mathrm{ml})$ & $<0.004$ & $<0.004$ & $<0.004$ & $<0.004$ \\
\hline $\mathrm{NA}(\mu \mathrm{g} / \mathrm{ml})$ & 0.857 & 6.004 & $>15.270$ & $>121.13$ \\
\hline $\mathrm{Ni}(\mu \mathrm{g} / \mathrm{ml})$ & $<0.005$ & $<0.005$ & $<0.005$ & 0.047 \\
\hline $\mathrm{Sn}(\mu \mathrm{g} / \mathrm{ml})$ & $<0.007$ & $<0.007$ & $<0.007$ & $<0.007$ \\
\hline $\operatorname{Sr}(\mu \mathrm{g} / \mathrm{ml})$ & 0.002 & 0.008 & 0.020 & 0.109 \\
\hline $\mathrm{Ti}(\mu \mathrm{g} / \mathrm{ml})$ & $<0.001$ & 0.026 & 0.002 & 0.012 \\
\hline $\mathrm{V}(\mu \mathrm{g} / \mathrm{ml})$ & $<0.001$ & $<0.001$ & $<0.001$ & $<0.001$ \\
\hline $\mathrm{B}(\mu \mathrm{g} / \mathrm{ml})$ & $<0.004$ & 0.086 & 0.066 & 0.133 \\
\hline $\mathrm{Cr}(\mu \mathrm{g} / \mathrm{ml})$ & $<0.004$ & $<0.004$ & $<0.004$ & 0.005 \\
\hline$P(\mu \mathrm{g} / \mathrm{ml})$ & 0.089 & 0.037 & 0.088 & 0.240 \\
\hline $\mathrm{Si}(\mu \mathrm{g} / \mathrm{ml})$ & $<0.006$ & 4.060 & 5.892 & 10.385 \\
\hline
\end{tabular}


Table 2. Germinations per dish, out of a possible 10 seeds per dish.

\begin{tabular}{lcccc}
\hline & Rain & Control & F6 & F1 \\
\hline 10 & 8 & 10 & 7 \\
10 & 8 & 7 & 3 \\
10 & 5 & 10 & 4 \\
& 8 & 8 & 10 & 8 \\
& 9 & 9 & 8 & 1 \\
& 9 & 7 & 9 & 5 \\
mean & 10 & 7 & 6 & 2 \\
\hline
\end{tabular}


Table 3. Root Length Statistics. Test Statistic is the $T$ Value. Which $T$ and $P$ Value are used is determined by the Test for Equal Variance.

\begin{tabular}{lcccc}
\hline Type & N & Mean & Std Dev & Std Error \\
Control & 60 & 11.745 & 8.818 & 1.138 \\
Rain & 77 & 12.186 & 8.246 & 0.940
\end{tabular}

\begin{tabular}{lccc} 
Variances & $T$ & $\mathrm{DF}$ & Prob $>\mathrm{TT}$ \\
\hline Unequal & -0.299 & 122.6 & 0.7658 \\
Equal & -0.301 & 135.0 & 0.7638
\end{tabular}

For HO: Variances are equal, $F^{\prime}=1.14 \quad \mathrm{DF}=(59,76) \quad$ Prob $>\mathrm{F}^{\prime \prime}=0.5783$

$\begin{array}{llrll}\text { Type } & \mathrm{N} & \text { Mean } & \text { Std Dev } & \text { Std Error } \\ \text { F1 } & 35 & 7.536 & 5.002 & 0.846 \\ \text { Rain } & 77 & 12.186 & 8.246 & 0.940\end{array}$

$\begin{array}{lrrr}\text { Variances } & T & \text { DF } & \text { Prob>TT1 } \\ \text { Unequal } & -3.678 & 101.0 & 0.0004 \\ \text { Equal } & -3.084 & 110.0 & 0.0026\end{array}$

For HO: Variances are equal, $\mathrm{F}^{\prime}=2.72 \quad \mathrm{DF}=(76,34) \quad$ Prob $>\mathrm{F}^{\prime}=0.0018$

$\begin{array}{lllll}\text { Type } & N & \text { Mean } & \text { Std Dev } & \text { Std Error } \\ \text { F6 } & 68 & 10.282 & 8.079 & 0.980 \\ \text { Rain } & 77 & 12.186 & 8.246 & 0.940\end{array}$

$\begin{array}{lccc}\text { Variances } & T & D F & \text { Prob>lTI } \\ \text { Unequal } & -1.402 & 141.4 & 0.1631 \\ \text { Equal } & -1.400 & 143.0 & 0.1636\end{array}$

For HO: Variances are equal, $F^{\prime}=1.04 \quad D F=(76.67) \quad P r o b>F^{\prime}=0.8674$ 
Table 3. (Con't) Root Length Statistics. Test Statistic is the T Value. Which $T$ and $P$ Value are used is determined by the Test for Equal Variance.

\begin{tabular}{|c|c|c|c|c|}
\hline Type & $\mathbf{N}$ & Mean & Std Dev & Std Error \\
\hline $\mathrm{F} 1$ & 35 & 7.536 & 5.002 & 0.846 \\
\hline F6 & 68 & 10.282 & 8.080 & 0.980 \\
\hline
\end{tabular}

\begin{tabular}{llll} 
Variances & $T$ & DF & Prob $>$ TI \\
\hline Unequal & -2.122 & 97.4 & 0.0363 \\
Equal & -1.836 & 101.0 & 0.0693
\end{tabular}

For HO: Variances are equal, $F^{\prime}=2.61 \quad D F=(67,34) \quad$ Prob $>F^{\prime}=0.0030$

$\begin{array}{lllll}\text { Type } & \mathrm{N} & \text { Mean } & \text { Std Dev } & \text { Std Error } \\ \text { Control } & 60 & 11.745 & 8.818 & 1.138 \\ \text { F6 } & 68 & 10.282 & 8.079 & 0.980\end{array}$

\begin{tabular}{lccc} 
Variances & $T$ & DF & Prob $>$ TT1 \\
\hline Unequal & 0.974 & 120.5 & 0.3321 \\
Equal & 0.979 & 126.0 & 0.3294
\end{tabular}

For HO: Variances are equal $F^{\prime}=1.19 \quad D F=(59,67) \quad P r o b>F^{\prime}=0.4861$

$\begin{array}{llrll}\text { Type } & \mathrm{N} & \text { Mea } & \text { Std Dev } & \text { Std Error } \\ \text { Control } & 60 & 11.745 & 8.818 & 1.138 \\ \text { Fl } & 35 & 7.536 & 5.002 & 0.846\end{array}$

$\begin{array}{llll}\text { Variaices } & \mathrm{T} & \mathrm{DF} & \text { Prob>rT1 } \\ \text { Unequal } & 2.968 & 93.0 & 0.0038 \\ \text { Equal } & 2.588 & 93.0 & 0.0112\end{array}$

For HO: Variances are equal, $F^{\prime}=3.11 \quad \mathrm{DF}=(59,34) \quad$ Prob $>\mathrm{F}^{\prime}=0.0006$ 

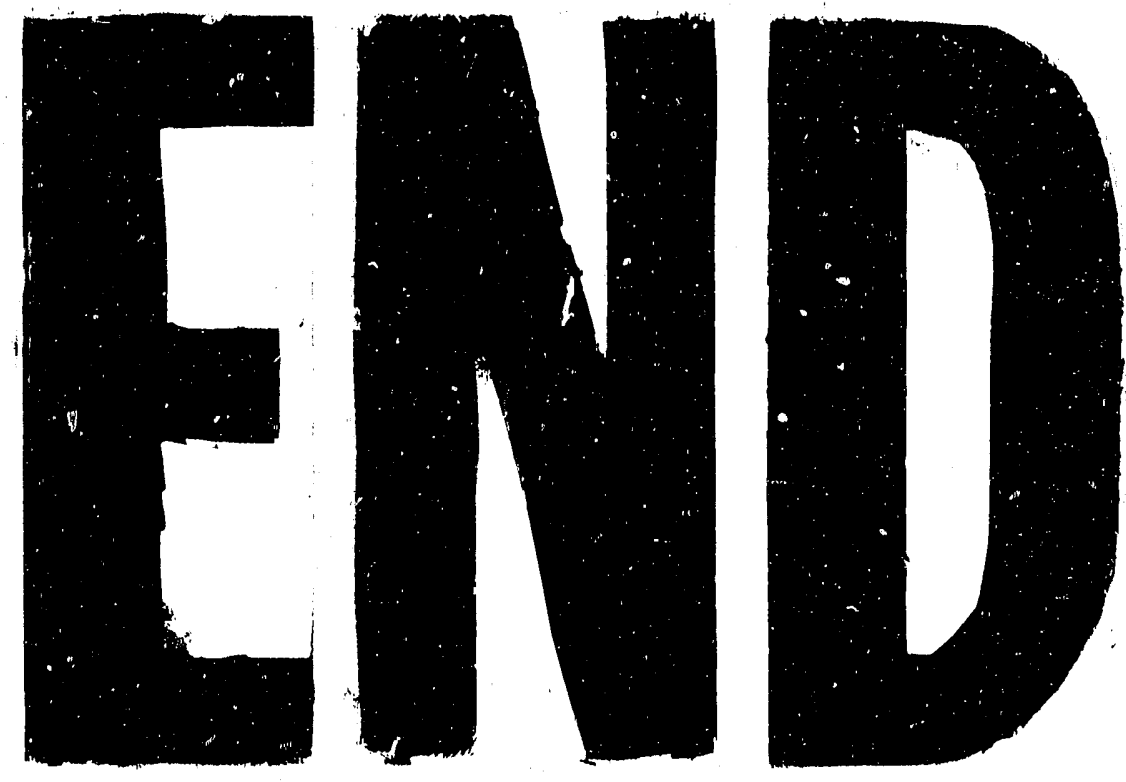

4
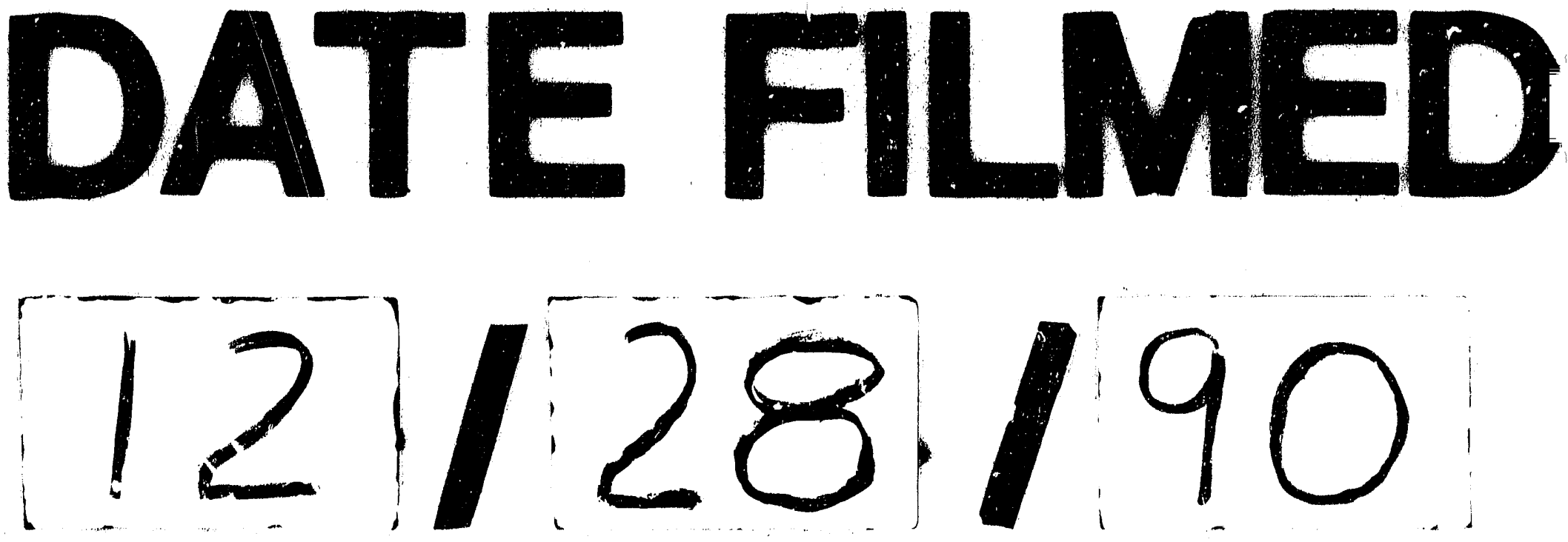